\title{
ADSORPTION OF ZINC IONS IN WATER ON N ATURAL AND TREATED CLAY
}

\author{
Mustapha Djebbar1, * , Fatiha Djafri²
}

https://doi.org/10.23939/chcht12.02.272

\begin{abstract}
Adsorption of zinc ions in water on natural and treated clay has been studied. Natural clay before and after activation was characterized using TGA/DTA techniques and chemical analysis. The effects of various parameters, such as an initial concentration, temperature, $\mathrm{pH}$, contact time and adsorbent concentration, has been examined. It was shown that treated clay is a good adsorbent compared to natural clay for removing $\mathrm{Zn}^{2+}$ ions and can be used instead of expensive adsorbents. The thermodynamic parameters have been calculated which have shown that the adsorption of $\mathrm{Zn}^{2+}$ on natural and activated clay is endothermic.
\end{abstract}

Keywords: activated clay, adsorption isotherm, thermodynamic parameters, montmorillonites, endothermic, exothermic.

\section{Introduction}

The elimination of pollutants and heavy metals from water and wastewater is important in terms of protecting public health and the environment [1].

Industrial activities are based on a number of pollutants such as fertilizers and battery manufacture, and dyeing in textile industries introduces heavy metals into the environment via their residual effluents [2]. Adsorption and ion exchange are the usual methods for the removal of organic and inorganic heavy metals from aqueous solutions [3].

Copper and zinc ions are identified with clinical problems [4]. They are found in soils, surface and underground waters by industrial discharges [5]. Copper and zinc ions as the pollutants, can be fixed by clay adsorption [6]. Studies devoted to the zinc fixation on clay minerals, bentonites namely, are not significant in

\footnotetext{
${ }^{1}$ Laboratory of Materials, Applications and Environment, Faculty of Science and Technology, University of Mascara, BP 763 Route de Mamounia, Mascara, Algeria

${ }_{2}$ Laboratoryof Chemical and Materials, Faculty of Science and Technology,

University of Oran, BP 1524 El Menouar, Oran, Algeria

* djebbar_mustapha@yahoo.fr

(C) Djebbar M., Djafri F., 2018
}

number $[7,8]$. To enhance the retention ability of clay minerals, they are chemically modified [9].The most important modification reactions in the adsorption are acid activation and cation exchange [10, 11]. Adsorption is one of the most efficient methods in the field of extracting heavy metals from aqueous solutions because of its simplicity and high efficiency [12, 14]. Some studies have been carried out to test the effectiveness of various types of clay of heavy metals adsorption from aqueous solutions [8, 13, 15-17].

The primary objective of this study is to evaluate the equilibrium adsorption of zinc ions on natural and treated clay, consisting mainly of secretite and montmorillonite.

\section{Experimental}

\section{1. $M$ aterials}

The clay used in this study was an Algerian clay treated and purified by the following method. The clay was washed with distilled and deionized water several times, and completely dispersed in water. After $7 \mathrm{~h}$ at least, the dispersion was centrifuged for $1 \mathrm{~h}$ at $2400 \mathrm{rpm}$. The size of the clay particles obtained was $2 \mu \mathrm{m}$. Then it was heated to $343 \mathrm{~K}$ in the presence of a solution composed of the sodium salts of $1 \mathrm{M}$ bicarbonate, $0.2 \mathrm{M}$ chloride and $2 \mathrm{M}$ citrate[18, 19] to eliminate the organic and inorganic compounds, present in inter-layer spaces. The carbonates were removed by adding $0.4 \mathrm{M} \mathrm{HCl}$ and the chloride was removed after several washings.

The organic matter was eliminated completely by treatment with $\mathrm{H}_{2} \mathrm{O}_{2}(30 \% \mathrm{v} / \mathrm{v})$ at $343 \mathrm{~K}$. The purified clay was dried at $383 \mathrm{~K}$, and then saturated with calcium $\left(\mathrm{Ca}^{+2}\right)$. To ensure complete transformation into the calcium form, all samples were washed several times with $\mathrm{Ca}(\mathrm{OH})_{2}$ solution $(1 \mathrm{M})$.

\subsection{M etal Solutions}

The aqueous solution was prepared using analytical $\mathrm{ZnCl}_{2}$ in $1000 \mathrm{ml}$ of ultrapure water. The concentration of metals in aqueous solutions submitted 
to zinc adsorption tests was determined by the PerkinElmer atomic absorption spectrophotometer.

$1.0 \mathrm{~g}$ of adsorbent and $100 \mathrm{ml}$ of metal solution were used at the initial concentration of $3.0 \mathrm{mg} / \mathrm{l}$ and $\mathrm{pH}$ 4.5. The value of $\mathrm{pH}$ was adjusted using $0.1 \mathrm{M} \mathrm{HCl}$ and $0.1 \mathrm{M} \mathrm{NaOH}$. The flasks were stored at room temperature $(296 \mathrm{~K})$ under constant stirring of $200 \mathrm{rpm}$. The adsorption capacity of zinc ion by natural and treated clay calculated from Eq.(1) is the difference between the final and initial concentrations:

$$
q_{e}=\frac{\left(C_{0}-C_{e}\right) \cdot V}{m}
$$

where $q_{e}$ is the amount of metal ions adsorbed on the clay, $1 \cdot \mathrm{mol} / \mathrm{g} ; C_{0}$ and $C_{e}$ are the initial and equilibrium concentrations in $1 \mathrm{M}$ solution, respectively, $\mathrm{mg} / \mathrm{l} ; V$ is the volume of medium, $1 ; m$ is the weight of the clay sample, $g$.

\subsection{Adsorption Isotherm Models}

To describe the relationship between the amount of adsorbed $\mathrm{Zn}$ ions and their equilibrium concentration two models (Freundlich and Langmuir) were used in this study.

Freundlich isotherm [20] is expressed as follows:

$$
q_{e}=K_{F} \sqrt[n]{C_{e}}
$$

where $C_{e}$ is an equilibrium concentration of the adsorbate, $\mathrm{mg} / \mathrm{l} ; q_{e}$ is the amount adsorbed under equilibrium, $\mathrm{mg} / \mathrm{g} ; K_{F}$ and $n$ are the Freundlich constants related to adsorption capacity and adsorption intensity of the adsorbent, respectively.

The linear form of the Freundlich isotherm model is given by the following relation:

$$
\ln q_{e}=\ln K_{F}+\frac{1}{n} \ln C_{e}
$$

Values of $K_{F}$ and $1 / n$ can be calculated from the linear slope between $\ln q_{e}$ and $\ln C_{e}$ [21].

The adsorption isotherm of Langmuir is based on the assumption of single-layer adsorption on the surface [21].

\subsection{Kinetic Studies}

The study of zinc ion kinetics was carried out using different concentrations $(20,50,100$ and $150 \mathrm{mg} / \mathrm{l}$ ). Under experimental conditions $\mathrm{pH}$ was 8 and 10; the weight of clay and zinc was 0.2 and $1 \mathrm{~g}$, respectively.

\section{Results and Discussion}

\subsection{Chemical Composition}

The chemical composition of the clay used for the experiments is shown in Table 1. It was determined by XRD analysis. On the basis of XRD results the structural formulas (Eqs. (4) and (5)) were derived, which are in agreement with the composition ofillite, as the predominant phase in the clay sample. Illite in clay was calculated by the XRD analysis showing the impurities of quartz. The sodium cation dominates in the illite interlayer; the sum of the $\left(\mathrm{Na}^{+}, \mathrm{Ca}^{2+}, \mathrm{K}^{+}\right)$ions exchangeable calculated by structure formula is equal to 0.057 , this charge indicates the presence of smectite.

$$
\begin{aligned}
& {\left[\mathrm{Si}_{3.53} \mathrm{Al}_{0.46}\right] \mathrm{O}_{10}\left(\mathrm{Mg}_{0.13} \mathrm{Al}_{0.76} \mathrm{Fe}^{\mathrm{III}}{ }_{0.25}\right)} \\
& (\mathrm{OH})_{2} \mathrm{~K}_{0.34} \mathrm{Ca}_{0.2} \mathrm{Na}_{0.06} \\
& {\left[\mathrm{Si}_{3.08} \mathrm{Al}_{0.92}\right] \mathrm{O}_{10}\left(\mathrm{Mg}_{0.17} \mathrm{Al}_{0.61} \mathrm{Fe}^{\mathrm{III}}{ }_{0.27}\right)} \\
& \quad(\mathrm{OH})_{2} \mathrm{~K}_{0.086} \mathrm{Ca}_{0.04} \mathrm{Na}_{0.061}
\end{aligned}
$$

\subsection{Thermal Analyses}

Fig. 1 shows the results of TGA analysis and Table 2 gives information corresponding to the clay fraction. The mass loss observed in the range of ambient temperatures and $473 \mathrm{~K}$ is related to the elimination of the adsorbed and intercalated water molecules. The mass loss due to evaporation and dehydroxylation is between 673-1073 K [23, 24].

Table 1

\section{Chemical composition of natural and treated clay}

\begin{tabular}{|c|c|c|c|c|c|c|c|c|}
\hline Oxides & $\mathrm{SiO}_{2}$ & $\mathrm{Al}_{2} \mathrm{O}_{3}$ & $\mathrm{Fe}_{2} \mathrm{O}_{3}$ & $\mathrm{MgO}$ & $\mathrm{Na}_{2} \mathrm{O}$ & $\mathrm{K}_{2} \mathrm{O}$ & $\mathrm{CaO}$ & $\mathrm{H}_{2} \mathrm{O}$ \\
\hline Natural Clay & 58.17 & 24.48 & 6.82 & 2.2 & 0.6 & 1.28 & 0.72 & 5.73 \\
\hline Treated Clay & 59.23 & 19.15 & 6.82 & 2.19 & 0.88 & 3.13 & 3.81 & 4.79 \\
\hline
\end{tabular}

Table 2

Thermogravimetric mass loss of clay

\begin{tabular}{|c|c|}
\hline Temperature, K & Mass loss, \% \\
\hline RT-473 & 8.69 \\
\hline $473-773$ & 2.04 \\
\hline $773-1073$ & 1.5 \\
\hline RT-1073 & 12.23 \\
\hline
\end{tabular}




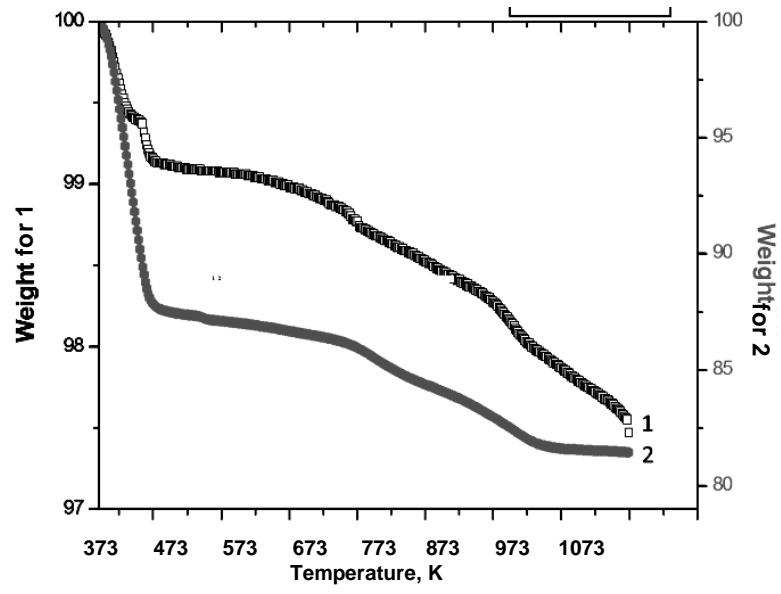

Fig. 1. TGA curve of treated (1) and natural (2) clay

\subsection{Effect of pH}

The study of $\mathrm{pH}$ effect on the zinc adsorption by clay is realized by metal solutions of $100 \mathrm{ml}$ in volume and $100 \mathrm{mg} / \mathrm{l}$ in concentration at $\mathrm{pH}$ ranging from 2 to 12. In this work the clay dose was kept constant $(0.2 \mathrm{~g})$ and the stirring time was determined at $3 \mathrm{~h}$ at $300 \mathrm{rpm}$. The results are shown in Fig. 2.

The highest efficiency of $\mathrm{Zn}^{2+}$ removal by adsorption on natural clay was obtained at $\mathrm{pH}>8$. At lower $\mathrm{pH}$ values the adsorption efficiency decreases. The effect of the $\mathrm{pH}$ changes depends on the adsorbent type and its behavior in the solution, as well as on the type of adsorbed ions [25]. In this work, the removal of $\mathrm{Zn}$ ion by the clay is optimized at $\mathrm{pH}$ values of $8-9$ or the cations present in the clay structure are exchanged for $\mathrm{Zn}$ ion present in the aqueous solution. At high values of $\mathrm{pH}$ the hydroxyl complexes of zinc, such as $\mathrm{ZnOH}^{+}$and $\mathrm{Zn}(\mathrm{OH})_{2}$ are formed. They can participate in adsorption and precipitate on the clay structure. Optimum $\mathrm{pH}$ values equal to 8.5 were used further to determine the effect of other factors such as clay dose, metal concentration, and agitation time.

\subsection{Effect of Clay Concentration}

In this study to determine the optimum concentration of clay, solutions with metal initial concentration of $100 \mathrm{mg} / \mathrm{l}$ were used at optimum $\mathrm{pH}$ values. During $5 \mathrm{~h}$ contact time, the amount of clay added to the solutions varied between 0.1 and $1 \mathrm{~g}$. The results are shown in Fig. 3.

During the removal of zinc, it was found that the adsorption efficiency increases as the amount of clay increases. The increase in efficiency is explained by the increase of the surface area where the adsorption takes place. The optimum clay concentration was found to be $0.6 \mathrm{~g} / 100 \mathrm{ml}$.

\subsection{Effect of $\mathrm{Zn}^{2+}$ Concentration}

Optimal concentrations were determined after experiments carried out at concentrations of $\mathrm{Zn}^{+2}$ ranging within $20-150 \mathrm{mg} / \mathrm{l}$. The adsorption efficiency increases at a certain level of saturation and remains stable with further increase in the concentration. The optimal concentration of $\mathrm{Zn}^{2+}$ was found to be $100 \mathrm{mg} / \mathrm{l}$. The results obtained from this study are shown in Fig. 4.

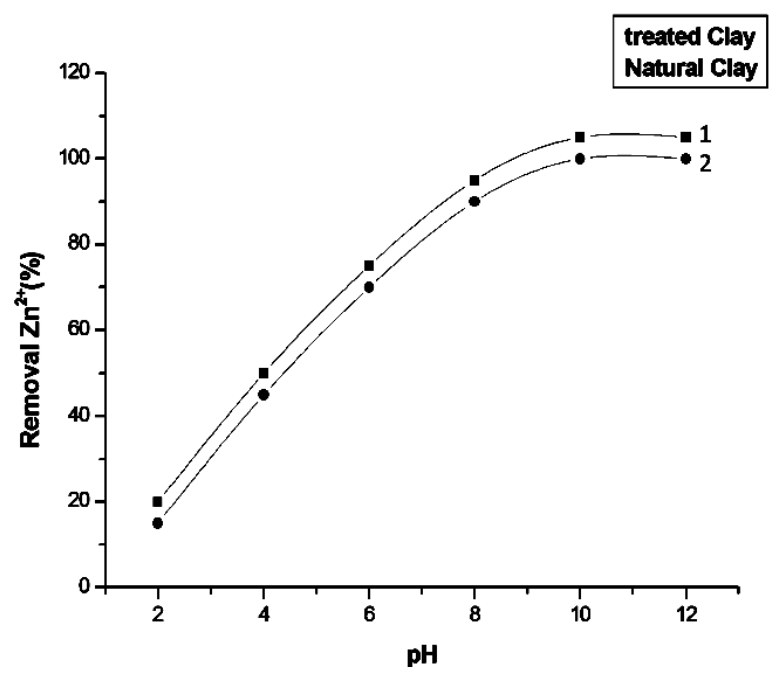

Fig. 2. Effect of pH on the $\mathrm{Zn}^{2+}$ removal by treated (1) and natural (2) clay. Initial concentration of zinc ions $100 \mathrm{mg} / \mathrm{l}$, clay concentration $0.6 \mathrm{~g} / 100 \mathrm{ml}$, contact time $5 \mathrm{~h}$ 


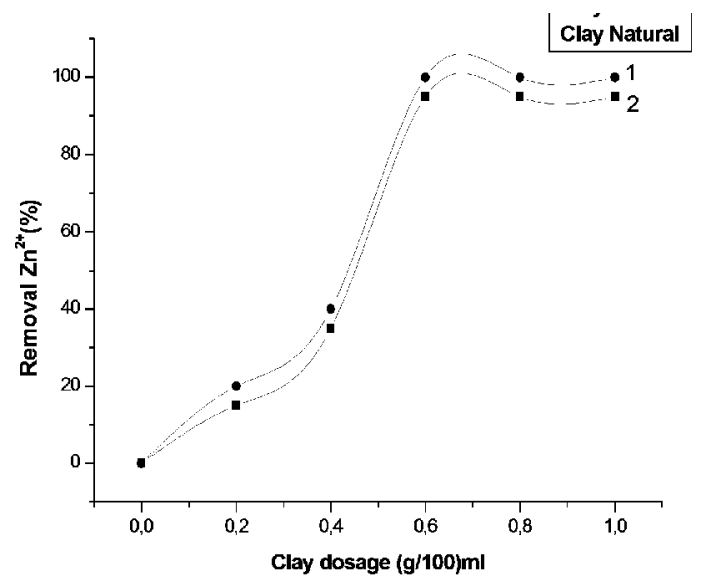

Fig. 3. Effect of clay concentration on the removal of $\mathrm{Zn}^{2+}$ by treated (1) and natural (2) clay. Initial concentration of zinc ions $100 \mathrm{mg} / \mathrm{l}, \mathrm{pH} 8-9$, contact time $5 \mathrm{~h}$

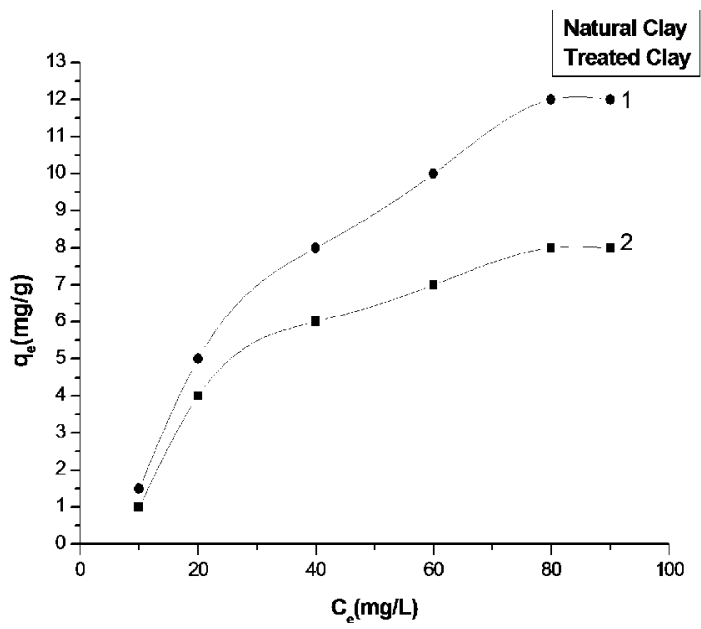

Fig. 4. Effect of $\mathrm{Zn}^{+2}$ concentration on the on the adsorption efficiency of treated (1) and natural (2) clay. Clay concentration $0.6 \mathrm{~g} / 100 \mathrm{ml}$; $\mathrm{pH} 8-9$; contact time $5 \mathrm{~h}$

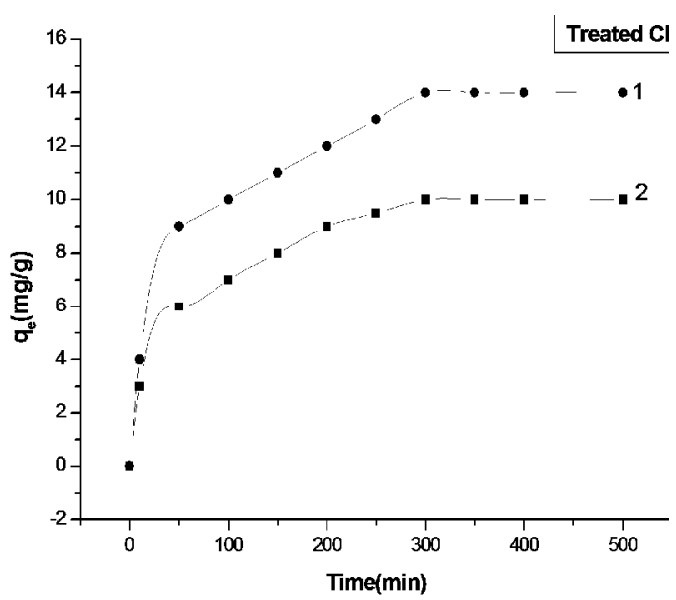

Fig. 5. Kinetic studies for $\mathrm{Zn}^{2+}$ adsorption on treated (1)

and natural (2) clay. Clay concentration $0.6 \mathrm{~g} / 100 \mathrm{ml}$; solution volume $100 \mathrm{ml}$; initial concentration zinc ion $100 \mathrm{mg} / \mathrm{l}$; contact time $5 \mathrm{~h}$; $\mathrm{pH}$ 7; temperature $293 \mathrm{~K}$ 


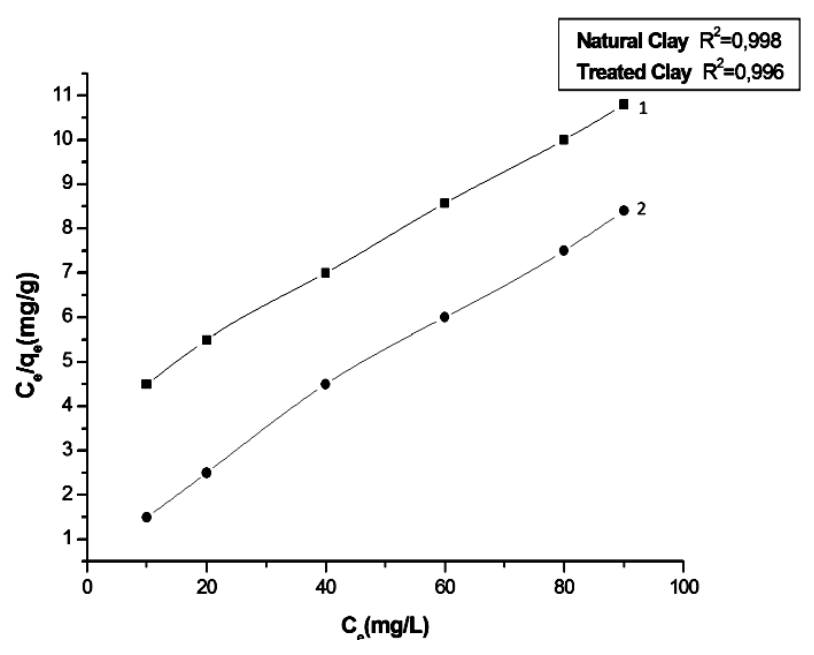

Fig. 6. Langmuir isotherms for $\mathrm{Zn}^{2+}$ adsorption on treated (1) and natural (2) clay. Clay concentration $0.6 \mathrm{~g} / 100 \mathrm{ml}$; solution volume $100 \mathrm{ml}$; initial concentration zinc ion $100 \mathrm{mg} / \mathrm{l}$; contact time $5 \mathrm{~h}$; $\mathrm{pH} 7$; temperature $293 \mathrm{~K}$

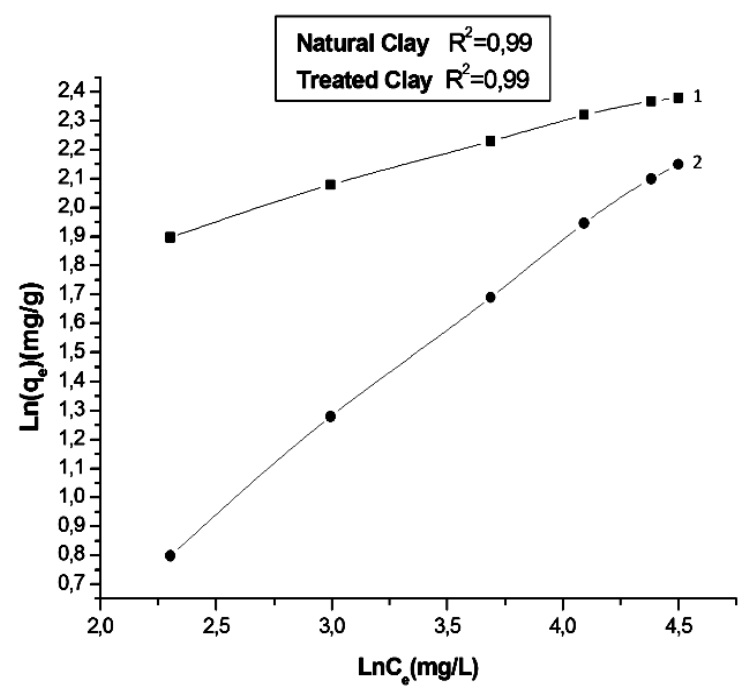

Fig. 7. Freundlich isotherms for $\mathrm{Zn}^{2+}$ adsorption on treated (1) and natural (2) clay. Clay concentration $0.6 \mathrm{~g} / 100 \mathrm{ml}$; solution volume $100 \mathrm{ml}$; initial concentration zinc ion $100 \mathrm{mg} / \mathrm{l}$; contact time $5 \mathrm{~h}$; $\mathrm{pH} 7$; temperature $293 \mathrm{~K}$

Table 3

Adsorption isotherm model constants for $\mathrm{Zn}^{2+}$ adsorption on natural and treated clay

\begin{tabular}{|l|c|c|c|c|c|c|}
\hline & \multicolumn{2}{|c|}{ The Langmuir isotherm constants } & \multicolumn{3}{c|}{ The Freundlich isotherm constants } \\
\cline { 2 - 7 } & $q_{0}, \mathrm{mg} / \mathrm{g}$ & $b, 1 / \mathrm{mg}$ & $R^{2}$ & $K_{f}$ & $1 / n$ & $R^{2}$ \\
\hline Natural clay & 11.79 & 0.1 & 0.996 & 0.58 & 0.6 & 0.9926 \\
\hline Treated clay & 12.92 & 0.02 & 0.998 & 4.05 & 0.21 & 0.9921 \\
\hline
\end{tabular}

\subsection{Kinetics of Adsorption}

The adsorption mechanism and above-mentioned characteristics are explained using the adsorption kinetics.
It is possible to verify from Fig. 5 that equilibrium is reached after $300 \mathrm{~min}$.

The monolayer capacity, $q_{0}$, for treated and natural clay was 12.92 and $11.79 \mathrm{mg} / \mathrm{g}$, respectively. The higher $b$ value of natural clay compared with that of 
treated clay showed that the adsorption of $\mathrm{Zn}^{2+}$ ions on the raw clay required more energy. The value of correlation coefficient $\left(R^{2}=0.99\right)$ is also good for treated and natural clay. It can be said that Freundlich model suitable for adsorption natural and treated clay.

\subsection{Thermodynamic Parameters}

Thermodynamic parameters for the adsorption of zinc ions by natural and treated clay can be calculated from the maximum variation in adsorption with temperature using the thermodynamic relationships [26].

According to Eqs.(7) and (8) the thermodynamic parameters are the change of enthalpy $\left(\Delta H^{0}\right)$, free energy of Gibbs $\left(\Delta G^{0}\right)$ and entropy $\left(\Delta S^{0}\right)$.

$$
\begin{array}{r}
K_{a d s}=Q_{e} \frac{\left(\frac{m}{v}\right)}{\left[C_{0}-C_{e}\left(\frac{m}{v}\right)\right]} \\
\Delta G^{0}=R T \ln K_{a d s} \\
\Delta S^{0}=\frac{\left(\Delta H^{0}-\Delta G^{0}\right)}{T}
\end{array}
$$

where $R$ is the gas constant, $R=8.314 \cdot 10^{-3} \mathrm{~kJ} / \mathrm{mol} \cdot \mathrm{K} ; K_{a d s}$ is the equilibrium constant; $T$ is the absolute temperature, $\mathrm{K} ; \Delta G^{0}$ is the change of free energy, $\mathrm{kJ} / \mathrm{mol} ; \Delta H^{0}$ is the change in enthalpy, $\mathrm{kJ} / \mathrm{mol} ; \Delta S^{0}$ is the change in entropy, $\mathrm{kJ} / \mathrm{mol}$; $v$ is the solution volume, $\mathrm{ml}$; $m$ is the weight of the clay sample, $\mathrm{g} ; C_{0}$ and $C_{e}$ are the initial and equilibrium concentrations.

According to Eq. (8), the mean value of the enthalpy change due do the adsorption of $\mathrm{Zn}^{2+}$ by natural and treated clay within the studied temperature range can be determined graphically by the linear plotting of $\ln K_{a d s}$ against $1 / T$ using the least squares method (Fig. 8). The calculated thermodynamic parameters are summarized in Table 4. Within the temperature range of 293-323 K, the values of $\Delta G^{0}$ for $\mathrm{Zn}^{2+}$ are negative indicating that adsorption is spontaneous. The adsorption capacity of $\mathrm{Zn}^{2+}$ adsorption on treated clay is higher than on natural clay because the lower the value of $\Delta G^{0}$, the more spontaneous and favorable is the adsorption.

The $\Delta H^{0}$ values for $\mathrm{Zn}^{2+}$ were found to be positive indicating that the adsorption process is endothermic; hence, the increase in temperature increases the metal adsorption capacity.Positive values of $\Delta S^{0}$ mean that there is the increase in the disordered character at the solid-solution interface of zinc ions on natural and treated clay [27].

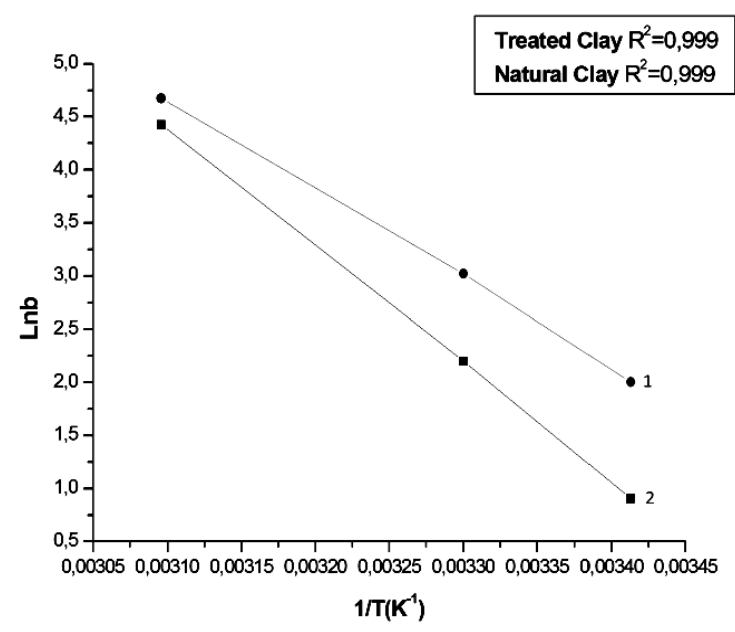

Fig. 8. Van't Hoff plots of $\mathrm{Zn}^{2+}$ adsorption on treated (1) and natural (2) clay

Table 4

Thermodynamic parameters for $\mathrm{Zn}^{2+}$ ion adsorption on natural and treated clay

\begin{tabular}{|c|c|c|c|c|}
\hline & Temperature, $\mathrm{K}$ & $\Delta G^{0}, \mathrm{~kJ} / \mathrm{mol}$ & $\Delta H^{0}, \mathrm{~kJ} / \mathrm{mol}$ & $\Delta S^{0}, \mathrm{~kJ} / \mathrm{mol}$ \\
\hline \multirow{3}{*}{ Natural clay } & 293 & -2.25 & \multirow{2}{*}{69.8} & \multirow{2}{*}{25.79} \\
\cline { 2 - 3 } & 303 & -5.47 & & \\
\cline { 2 - 3 } & 323 & -11.90 & \multirow{2}{*}{92.13} & \multirow{2}{*}{32.23} \\
\hline \multirow{2}{*}{ Treated Clay } & 293 & -4.95 & -7.50 & \\
\hline & 303 & -12.60 & & \\
\hline & 323 & & & \\
\hline
\end{tabular}

\section{Conclusions}

$\mathrm{Zn}^{2+}$ was removed from the solutions by natural clay from Algeria. Treated clay increased the adsorption capacity. The adsorption reached the maximum at $\mathrm{pH} 8.5$ and increased with the increase in temperature. The isotherms could be described by the Langmuir model. The monolayer capacity for treated and natural clay was found to be 12.92 and $11.79 \mathrm{mg} / \mathrm{g}$, respectively. The adsorption process was spontaneous and endothermic. The amount of $\mathrm{Zn}^{2+}$ adsorbed by natural clay is lower compared with treated clay.

\section{Acknowledgements}

The authors thank Prof. F. Djafri for his guidance and support throughout this research. 


\section{References}

[1] Unlu N., Ersoz M.: J. Hazard. Mater. B, 2006,136, 272. https://doi.org/10.1016/j.jhazmat.2005.12.013

[2] Srivastava V., Mall I., Misha I.: J. Hazard. Mater. B, 2006,134,

257. https://doi.org/10.1016/j.jhazmat.2005.11.052

[3] Das N., Kumar J.: J. Colloid Interf. Sci., 2006, 293, 253. https://doi.org/10.1016/j.jcis.2005.06.064

[4] Caussy D., Gochfeld M., Gurzau E. et al.: Ecotox. Environ. Safe., 2003, 25, 45. https://doi.org/10.1016/S01476513(03)00049-6

[5] Nachtegaal M., Sparks D: J. Colloid Interf. Sci., 2004, 276, 13. https://doi.org/10.1016/j.jcis.2004.03.031

[6] Kiekens L.: Zinc [in:] Alloway B. (Ed.), Heavy Metals in Soils, 2nd edn. Blackie Academic and Professional, London1995, 284-305.

[7] Mellah A., Chegrouche S.: Water Res., 1997, 31, 621. https:// doi.org/10.1016/S0043-1354(96)00294-1

[8] Kaya A., Hakan Oren A.: J. Hazard. Mater. B, 2005, 125,183. https:// doi.org/10.1016/j.jhazmat.2005.05.027

[9] Bergaya F., Lagaly G.: Appl. Clay Sci., 2001, 19, 1.

https://doi.org/10.1016/S0169-1317(01)00063-1

[10] Komadel P.: Clay Miner., 2003, 38, 127.

https://doi.org/10.1180/0009855033810083

[11] Komadel P., Madejová J.: Handbook Clay Sci., 2006, 1, 263. https://doi.org/10.1016/S1572-4352(05)01008-1

[12] Sdiri A., Higashi T., Hatta T. et al.: Chem. Eng. J., 2011, 172, 37. https://doi.org/10.1016/j.cej.2011.05.015

[13] Ulmanu M., Marañón E., Fernández Y. et al.: Water Air Soil Poll., 2003, 142, 357. https://doi.org/10.1023/A:1022084721990

[14] Sdiri A., Higashi T., Jamoussi F., Bouaziz S.: Environ.

Manage. J., 2012, 93, 245.

https://doi.org/10.1016/j.jenvman.2011.08.002

[15] Eren E., Afsin B., Onal Y.: Hazard. Mater. J., 2009, 161, 677. https://doi.org/10.1016/j.jhazmat.2008.04.020

[16] Ozdes D., Duran C., Senturk H.: Environ. Manage. J., 2011, 92, 3082. https://doi.org/10.1016/j.jenvman.2011.07.022

[17] Lin S., Juang R.: J. Hazard. Mater., 2002, 92, 315.

https://doi.org/10.1016/S0304-3894(02)00026-2
[18] Pusino A., Micera G., Gessa C., Petretto S.: Clays Clay Miner., 1989, 37, 558.

https://doi.org/10.1346/CCMN.1989.0370609

[19] Robert M., Tessier D.: Ann. Agron, 1974, 25, 859.

[20] Freundlich H.: J. Phys. Chem., 1906, 57, 385.

[21] Langmuir I.: J. Am. Chem. Soc., 1918, 40, 1361. https://doi.org/10.1021/ja02242a004

[22] Sdiri A., Higashi T., Chaabouni R., Jamoussi F.: Water Air Soil Pollut., 2012, 223,1191 . https://doi.org/10.1007/s11270-011-0937-z [23] AyariaF., Srasrab E., Trabelsi-Ayadia M.: Desalination, 2005, 185, 391. https://doi.org/10.1016/j.desal.2005.04.046 [24] Yurdakoc M., Akçay M., Tonbul Y. et al.: Micropor. Mesopor. Mat., 2008, 111, 1387.

https://doi.org/10.1016/j.micromeso.2007.07.032

[25] Veli S., Pekey B.: Fresenius Environ. Bull, 2004, 13, 244.

[26] Seki Y., Yurdakoc K.: Adsorption, 2006, 12, 89. https://doi.org/10.1007/s10450-006-0141-4

[27] Bayramoğlu G., Arıca M.: Chem. Eng. J., 2008, 143, 133. https://doi.org/10.1016/j.cej.2008.01.002

Received: July 15, 2017 / Revised: November 07, 2017 /

Accepted: January 09, 2018

\section{АДСОРБЦІЯ ЙОНІВ ЦИНКУ У ВОДІ НА ПРИРОДНИХ ТА АКТИВОВАНИХ ГЛИНАХ}

Анотація. Досліджено адсорбиію йонів ичинку у воді на природних та активованих глинах. За допомогою методів ТГА/ДТА та хімічного аналізу визначено характеристики природної глини до і після активачії. Досліджено вплив різних параметрів, таких як вихідна кониентрація, температура, pH, час контакту та концентрація адсорбенту. Показано, щчо активована глина є кращим адсорбентом для видалення йонів $\mathrm{Zn}^{2+}$ у порівнянні з природною $і$ може використовуватися замість дорогих адсорбентів. Розраховані термодинамічні параметри, які показали, щзо адсорбція $\mathrm{Zn}^{2+}$ на природній та активованій глині є ендотермічним процесом.

Ключові слова: активована глина, ізотерма адсорбиії, термодинамічні параметри, монтморилоніти, ендотермічний, екзотермічний. 